\title{
Taxonomic, phylogenetic and functional diversity of leeches (Hirudinea) and their suitability in biological assessment of environmental quality
}

\author{
Paweł Koperski* \\ Department of Hydrobiology, Faculty of Biology, Center of Biological and Chemical Research, University of Warsaw, Zwirki i \\ Wigury101, 02-089 Warszawa, Poland
}

\begin{abstract}
Different components of biological diversity of leeches (Hirudinea), sampled in lowland watercourses in Poland were compared between sites differed in terms of environmental quality, measured by officially approved procedures. Indices based on taxonomic diversity, rarefied species richness, taxonomic distinctness, phylogenetic diversity and functional diversity were considered in the analysis, for sites belonging to three biocoenotic types of watercourses. In most cases values of all indices except Pielou's evenness show unimodal relationships with environmental quality and in any case monotonic increase in diversity was not shown. Median values of diversity were significantly higher and its highest values were significantly more frequent at sites with moderate than with low or high environmental quality. This pattern of relationships was observed both for indices based on presence/absence data and those based on relative abundance of species. The significance of this mode of relationships differed between biocoenotic types and between procedures using to measure environmental quality. The results obtained show low and doubtful usefulness of each component of leech diversity as an element of biological assessment in lowland watercourses.
\end{abstract}

Keywords: taxonomic diversity / phylogenetic diversity / functional diversity / Hirudinea / biological assessment

Résumé - Diversité taxonomique, phylogénétique et fonctionnelle des sangsues (Hirudinea) et leur aptitude à l'évaluation biologique de la qualité environnementale. Différentes composantes de la diversité biologique des sangsues (Hirudinea), échantillonnées dans les cours d'eau de plaine en Pologne, ont été comparées entre des sites différents en termes de qualité environnementale, mesurée par des procédures officiellement approuvées. Les indices fondés sur la diversité taxonomique, la richesse en espèces raréfiées, la diversité phylogénétique et la diversité fonctionnelle ont été pris en compte dans l'analyse, pour des sites de cours d'eau appartenant à trois types biocénotiques. Dans la plupart des cas, les valeurs de tous les indices, à l'exception de l'équitabilité de Pielou, montrent des relations unimodales avec la qualité de l'environnement et, en tout état de cause, une augmentation monotone de la diversité. Les valeurs médianes de la diversité étaient significativement plus élevées et les valeurs les plus élevées étaient significativement plus fréquentes dans les sites de qualité environnementale modérée plutôt que faible ou élevée. Ce patron de relations a été observé à la fois pour les indices fondés sur les données de présence/ absence et ceux fondés sur l'abondance relative des espèces. L'importance de ce mode de relations différait entre les types de biocénoses et entre les procédures utilisées pour mesurer la qualité de l'environnement. Les résultats obtenus montrent que chaque composante de la diversité des sangsues est peu utile et douteuse en tant qu'élément de l'évaluation biologique dans les cours d'eau de plaines.

Mots-clés : diversité taxonomique / diversité phylogénétique / diversité fonctionnelle / Hirudinea / évaluation biologique

\footnotetext{
*Corresponding author: p.t.koperski@uw.edu.pl
} 


\section{Introduction}

Environmental (ecological) quality (EQ) as a general term is a "set of properties and characteristics of the environment as they impinge on organisms" (European Environment Agency, 2012). When applied to aquatic ecosystems EQ is an overarching term coined by the Water Framework Directive (WFD, Directive 2000/60/EC of the European Parliament and of the Council 2000) and is defined as a quality of structure and functioning of an ecosystem (Furse et al., 2006). EQ can be also described as the inverse of the total effect of many factors constituting together the ecological impact or ecological stress observed in ecosystem. It can be quantified and used in biological assessment if such effects will be standardized and then compared with those under natural (reference) conditions (Hering et al., 2003). Thus, it would appear reasonable to analyse the diversity of organisms in relation to environmental quality treated as a measure of the intensity of ecological stress.

Biological diversity of aquatic organisms is considered in WFD (Directive 2000) as being among the most important parameter characterizing structure and functioning of lotic environments and describing the ecological status and environmental quality of an ecosystem. The influence of different ecological stressors on biological diversity is one of the most important and most intensively researched the problems of modern ecology (Darling and Côté, 2008; Jackson et al., 2016). Thus, the values of different measures of biological diversity can be treated both as the result of natural and anthropogenic ecological stress and as a parameter used to assess their intensity. The negative impact of such factors on biological diversity of benthic invertebrates in freshwater environments is frequently assumed in numerous studies (e.g. Reice, 1985; Lorenz et al., 2004; Sánchez-Montoya et al., 2010; Stranko et al., 2012), but the lack of such direct effects was also found (e.g. Heino et al., 2007).

On the other hand, certain well-known and widely discussed models try to describe the mechanisms of the commonly observed unimodal (hump-like, peaked) relationship observed in the gradient of different disturbing factors. The explanations of the mechanism leading to higher taxonomic richness at moderate levels of stressor intensity have been proposed by Collins and Barber (1986) and Collins et al. (1995) as the intermediate disturbance hypothesis, by Huston (1979) as the dynamic equilibrium model and later as other models by, e.g. Porter et al. (2001), Kondoh (2001), Tonkin et al. (2013). IDH seems to be a one of the most widely discussed modern concepts concerning biological diversity in unimodal relation to ecological impact (e.g. Wilkinson, 1999; Svensson et al., 2012). While the critical approach to these models focuses primarily on showing weaknesses in predictive modelling of causal mechanisms describing relationships between populations and disturbing factors (e.g. Fox, 2013), specialists agree that the maxima of biodiversity typically occur at their intermediate intensity.

The reaction of different components of biological diversity to increase intensity of environmental stress in freshwaters can be carried out according to at least two different types of responses: monotonic decrease or unimodal. The type of response may be dependent (among the others) on the level of taxonomic identification (Wright et al., 1995; Wright and Ryan,
2016), type of stressor (Gutiérrez-Cánovas et al., 2013) and spatial scale of an analysis (Heino et al., 2003). Determining which type of response is responsible for relationships between EQ at a sampling site and the diversity of different groups of benthic animals is important from the point of view of biological assessment. Monotonic decrease in abundance or diversity along the gradient of ecological stress is one of the most important reason why a given taxon has high indicative value (Hering et al., 2006b). It seems that the unimodal relationship between environmental quality and the diversity of a taxon makes the latter unsuitable in biological assessment.

Most of the bioassessment methods based on the taxonomic composition, abundance and diversity of many groups of benthic fauna and Hirudinea are used as one of many measured metrics. The history of the use of diversity indices in freshwater monitoring is long and complex and involves numerous methods (Magurran, 2013), especially the diversity of benthic invertebrates has been expressed in biological assessment in different ways (Bailey et al., 2004). Leeches are used as a group included in macrobenthos, which is the basic element of monitoring in freshwater habitats, as is required by WFD (Directive 2000/60/EC). Observations that particular taxa of Hirudinea have an indicative value in the biological assessment of environmental quality are common in the literature (Grosser et al., 2001; Koperski, 2005; Kubová et al., 2013; Kazanci et al., 2015). Abundance, percentage and diversity of Hirudinea, treated as ones of moderately tolerant taxa are taken into account in practical bioassessment protocols (Armitage et al., 1983). Leeches are often used as an element of standardized metrics (family richness, Shannon diversity index, ASPT index) clearly responding to organic pollution, changes in stream morphology, acidification and general environmental degradation (Bis and Mikulec, 2013). The level of pollution in lowland streams correlates stronger with changes in taxonomic diversity of leeches than of certain commonly occurred groups of benthic invertebrates like, e.g. Chironomidae and Odonata (Koperski, 2010). Due to the low species richness of European leeches, the relative easiness of their taxonomic determination and widespread occurrence in different types of watercourses, this group seems to be potentially very useful for the assessment of the ecological status of lotic environments. Phylogenetic relationships among leeches based on modern molecular methods seems to be relatively better understood than among many other groups of freshwater animals. However, erroneous taxonomic identification in Hirudinea impedes a clear understanding of their phylogeny and diversity. European leech species are highly divergent in terms of their ecological preferences: some of them are common and tolerant for water pollution ( $e$. g. Erpobdella octoculata, Glossiphonia complanata) while other ones are more sensitive (E. vilnensis, G. nebulosa) or even treated as highly specialized (Calliobdella mamillata, Trocheta bykowskii). Indicative values of Hirudinea for purposes of biological assessment are typically determined on the level of family: in BMWP method (Wright et al., 1989), in its Polish modification BMWPpl (Kownacki and Soszka, 2004) and in recently developed official Polish index MMI (Bis and Mikulec, 2013).

Many indices of diversity allow us to compare different aquatic communities in different types of environments, but their divergence makes biological diversity difficult to 
quantify for the purposes of biological assessment. Treating species as being equal in spite of their functional divergence and phylogenetic distance seems to be an important weakness of traditional measures of taxonomic diversity (Schweiger et al., 2008) and the use of taxonomic diversity indices based on identification to a level higher than the species is prone to different errors (Koperski, 2010, 2011; Šiling and Urbanič, 2016). Three groups of methods have been developed to solve these problems: taxonomic distinctness (e.g. Warwick and Clarke, 1995), phylogenetic diversity based on mutual evolutionary relationships between species (e.g. Faith and Baker, 2006) and functional diversity based on the analysis of the biological traits of benthic animals (e.g. Usseglio-Polatera et al., 2000; Statzner et al., 2005). These components of diversity provide certain additional value to theoretical and applied ecology (Mason et al., 2005; Schweiger et al., 2008). Vamosi and Vamosi (2007) and Carew et al. (2011) suggest that biological assessment of freshwater environments based on phylogenetic data on certain smaller taxa seems to be potentially effective and reliable.

The main aims of the study were:

- to determine the modes of relationships between diversity of leeches in lowland watercourses and environmental quality;

- to determine the suitability of leeches' diversity for the purposes of biological assessment on the basis of the modes of these relationships.

The most probable modes of distribution of the diversity along the gradient of environmental quality are: (i) monotonic - the higher EQ, the higher diversity and (ii) unimodal - the highest level of diversity observed at sites with moderate EQ. The study was also aimed into searching and comparing the differences in these relationships between

- different components of diversity, those measured by traditional diversity indices as well as taxonomic distinctness, phylogenetic diversity and functional diversity;

- different types of lowland watercourses.

\section{Methods}

The analysis was performed on the basis of data on benthic invertebrates collected from 268 sites at watercourses on territory of Poland (Fig. 1). Samples were collected once at each site between 2010 and 2012 by Regional (Voivodship) Inspectorates of Environmental Protection (RIEP) and by the scientific team cooperating with the National Foundation of Environmental Protection, Warsaw, Poland. Sampling was performed in accordance with the procedure recommended after minor modifications under the name RIVECO to assess the ecological status of flowing waters and conform with the requirements of the WFD (Bis and Mikulec, 2013). Leeches were separated from the samples and then identified on the basis of the key by Nesemann and Neubert (2000). All individuals were identified to species level. Only samples including at least two individuals belonging to at least two species were taken into consideration to analysis.

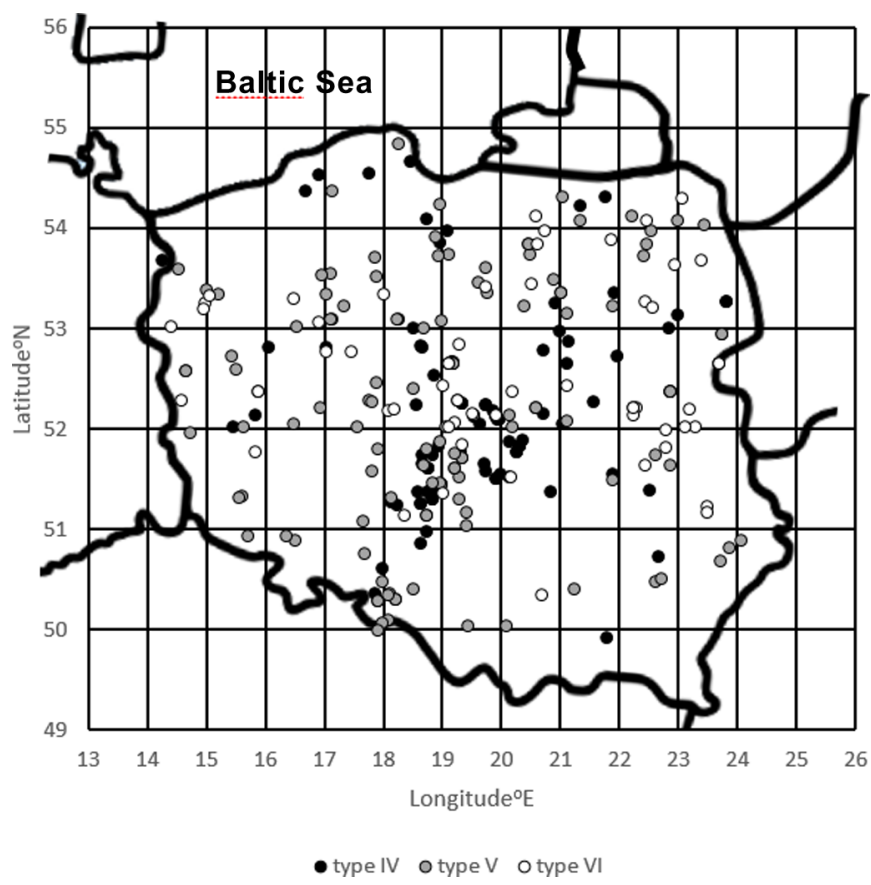

Fig. 1. Map of Poland showing 268 sampling sites, belonging to the three biocoenotic types.

The ecological status at each sampling site was taken from the data-bases available on the RIEP's websites (available at web portal http://www.gios.gov.pl/). The classification is based on the results of biological assessment expressed by the values of BMWPpl and MMI indices as they occurred between 2010 and 2012. Each sampling site was classified to adequate one of 26 abiotic types of watercourses described for Poland, and then classified into one of the three biocoenotic types of watercourses (type IV - lowland sandy streams, 94 sites; type V estuarine rivers and lowland streams and rivers other than in types IV and VI, 114 sites; type VI - lowland streams and rivers with organic bottoms and lowland streams and rivers connecting lakes, 60 sites) chosen from six types described for Poland (Bis and Mikulec, 2013) on the basis of RIEPs' databases (Fig. 1). All analyses were performed separately for each biocoenotic type.

Data on the geographical variables (parameters) at each site: latitude, longitude, altitude and distance from the site to the source have been obtained from the Geoportal website (http://mapygeoportalgovpl/).

\subsection{Biological diversity}

Five components of biological diversity (1-5) were taken into account to assess its relationships with EQ. Nine indices describing leech diversity were calculated for each sample:

- Richness - to assess species richness in samples with different sizes, containing data on abundances Krebs' individual rarefaction procedure (IR) was used (PAST software) while to assess rarefied number of species in groups of samples containing presence/absence data procedure of Mao Tau sample rarefaction (SR) was applied (PAST software). 
Q2 Table 1. Taxonomic composition of leeches sampled in the studied sites, classified to three biocoenotic types and presented as the frequency of occurrence. Basic parameters characterizing sites are added.

\begin{tabular}{|c|c|c|c|c|}
\hline \multirow[t]{2}{*}{ Species } & \multicolumn{3}{|c|}{ Biocoenotic type } & \multirow[t]{2}{*}{ Total } \\
\hline & IV & $\mathrm{V}$ & VI & \\
\hline Alboglossiphonia heteroclita (L.) & 9.6 & 7.9 & 16.7 & 10.4 \\
\hline Alboglossiphonia hyalina (O.F. Müller) & 0 & 0.9 & 0 & 0.4 \\
\hline Alboglossiphonia striata (Apáthy) & 0 & 2.6 & 3.3 & 1.9 \\
\hline Caspiobdella fadejevi (Epshtein) & 0 & 3.5 & 0 & 1.5 \\
\hline Dina apathyi Gedroyć & 0 & 0.9 & 0 & 0.4 \\
\hline Dina lineata (O.F. Müller) & 1.1 & 2.6 & 3.3 & 2.2 \\
\hline Erpobdella monostriata (Lindenfeld et Pietruszyński) & 1.1 & 0.9 & 1.7 & 1.1 \\
\hline Erpobdella nigricollis (Brandes) & 37.2 & 40.4 & 33.3 & 37.7 \\
\hline Erpobdella octoculata (L.) & 97.9 & 94.7 & 66.7 & 89.6 \\
\hline Erpobdella testacea (Savigny) & 4.3 & 3.5 & 5.0 & 4.1 \\
\hline Erpobdella vilnensis Liskiewicz & 21.3 & 13.2 & 41.7 & 22.4 \\
\hline Glossiphonia complanata (L.) & 52.1 & 43.0 & 10.0 & 38.8 \\
\hline Glossiphonia concolor (Apáthy) & 12.8 & 13.2 & 10.0 & 12.3 \\
\hline Glossiphonia nebulosa Kalbe & 13.8 & 10.5 & 0 & 9.3 \\
\hline Glossiphonia paludosa (Carena) & 1.1 & 0 & 1.7 & 0.7 \\
\hline Haemopis sanguisuga (L.) & 22.3 & 10.5 & 11.7 & 14.9 \\
\hline Helobdella stagnalis (L.) & 34.0 & 44.7 & 38.3 & 39.6 \\
\hline Hemiclepsis marginata (O.F.Müller) & 7.4 & 8.8 & 10.0 & 8.6 \\
\hline Piscicola geometra $(\mathrm{L})$. & 2.1 & 3.5 & 1.7 & 2.6 \\
\hline Placobdella costata (Fr. Müller) & 2.1 & 2.6 & 1.7 & 2.2 \\
\hline Theromyzon tessulatum (O.F. Müller) & 1.1 & 2.6 & 5.0 & 2.6 \\
\hline Species richness (range/median) & $2-9 / 3$ & $2-8 / 3$ & $2-7 / 3$ & 21 \\
\hline Abundance (range/mediane) & $3-314 / 17$ & $3-202 / 11$ & $3-184 / 12$ & \\
\hline Individuals & 2574 & 2531 & 1562 & 6667 \\
\hline BMWPpl (range/median) & $18-129 / 54.5$ & $18-165 / 74.5$ & $14-140 / 70$ & \\
\hline MMI (range/median) & $0.086-0.968 / 0.481$ & $0-0.942 / 0.492$ & $0.016-0.904 / 0.532$ & \\
\hline Number of samples & 94 & 114 & 60 & 268 \\
\hline
\end{tabular}

- Species diversity - two widely known and commonly used indices of diversity were chosen: Shannon index and Pielou evenness index $\mathbf{J}^{\prime}$.

- Distinctness - two indices based on number of taxonomic levels between pairs of species in a sample were used: taxonomic diversity index (TDI, Clarke and Warwick, 1998, PAST software) to analyze data on species abundance while the net relatedness index (NRI) (Webb, 2000) was applied to analyze presence/absence data.

- Phylogenetic diversity - estimated genetic distances between leech species were revealed on the basis of the distance matrix constructed on the basis of previously published data. The distance between each pair of species was determined on the basis of the standardized, relative average or resultant distance between species presented by Siddall and Burreson (1998), Apakupakul et al. (1999), Utevsky and Trontelj (2004), Siddall et al. (2005), Rousset et al. (2007), Oceguera-Figueroa et al. (2011), Kaygorodova and Mandzyak (2014), and Kaygorodova et al. (2014). For this purpose distances were estimated only on the basis of individuals collected in Central or Northern Europe. The average values of genetic distance within closely related group of species was applied in case of the lack of published data on distance between certain, relatively rare species within genera Alboglossiphonia (A. hyalina, A. striata) and Glossiphonia (G. nebulosa, G. paludosa). Mean phylogenetic distance (MPD) between pair of species in a sample (Vellend et al., 2011) was applied to analyze presence/absence data while Rao's quadratic entropy (QE) (Botta-Dukát, 2005) calculated for estimated phylogenetic distance was applied to analyse data on species abundance. To calculate this index software package FunctDiv was used (Lepš et al., 2006).

- Functional diversity - value of Rao's index (RAO) for each sample based on functional traits dissimilarity was calculated using software package FunctDiv (Lepš et al., 2006). For this purpose values of eight traits was determined for each species: diet, feeding mode, width of the feeding niche, parental care, amphibiotic life style, size of the body, morphological variability, habitat specialization.

To calculate values of taxonomic distinctness and phylogenetic diversity two software procedures were created in Visual Basic (Koperski and Meronka, 2017) and applied into the data base in the Excel 2013 software package, Microsoft Office. Values of all indices are presented as the first, second (median) and third quartile, percentile 0.9 and maximal value in each group of sites, independently for each biocoenotic type of watercourses. Groups contain sites in classes of $0.1 \mathrm{MMI}$ or 10 points of BMWPpl (e.g. 0.11-0.20, 0.21-0.30 MMI and 21-30 BMWPpl). The limits separating low, moderate and 


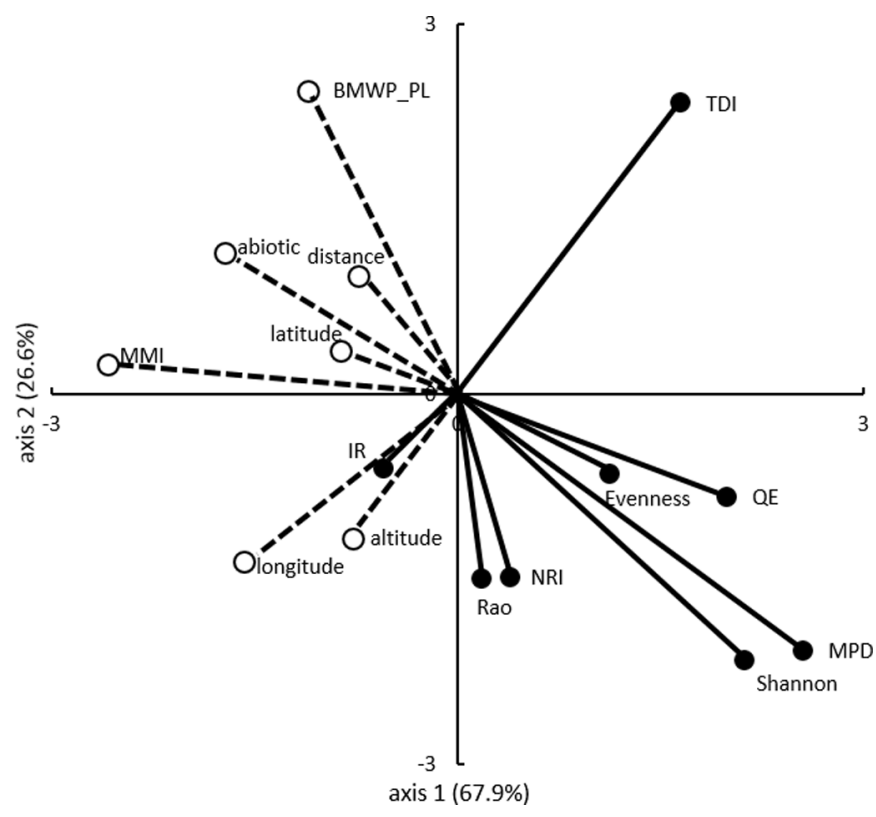

Fig. 2. Results of canonical correspondence analysis presented as an ordination map, where the components of leech diversity are shown as vectors pointed with black circles and environmental parameters and metrics shown as vectors pointed with white circles. Percentages of variance explained by each axis (canonical function) are added.

high values of BMWPpl and MMI were established for sites of each biocoenotic type on the basis of relative number of sites included into groups. In IVth type of watercourses moderate values of EQ range between 30 and $80 \mathrm{BMWPpl}$ and between 0.3 and $0.7 \mathrm{MMI}$, in Vth type between 40 and $100 \mathrm{BMWP}$ and between 0.3 and $0.8 \mathrm{MMI}$ and in VIth type between 40 and 90 BMWPpl and between 0.4 and $0.8 \mathrm{MMI}$.

\subsection{Numerical analysis}

Relationships obtained between different components of leech diversity in samples and environmental parameters (indices expressing environmental quality, abiotic type and the geographical parameters of altitude, longitude, latitude and distance from the source to the sampling site) were assessed with canonical correspondence analysis (CCA, PAST software). It was performed to show the relative importance of relationships between and among variables divided into two groups: metrics characterizing leech diversity and geographical/environmental parameters describing sampling sites (Legendre and Legendre, 2012).

\subsection{Statistical analysis}

Values of different diversity indices were compared between sites belonging to groups with moderate values of EQ indices and those belonging to groups with extreme (over and under limits) values (PAST software). Mann-Whitney's test was used to compare medians while the contingency tables approximated with $\mathrm{Chi}^{2}$ function were used to compare number of values belonging to percentile 0.9 between groups of moderate and extreme values of EQ.

\section{Results}

In 268 samples analyzed in this study 6667 individuals were found and identified to 21 species. During the study, four wide spread species were detected, among which E. octoculata was the most common, being collected in $c a .90 \%$ of samples, while three other species occurred with frequency more than 30\% (Erpobdella nigricollis, G. complanata, Helobdella stagnalis). Six species should be treated as rare (Dina apathyi, Alboglossiphonia hyalina, A. striata, Caspiobdella fadejewi, Erpobdella monostriata, Glossiphonia paludosa) because their frequency of occurrence did not range $2 \%$ (Tab. 1).

Results of CCA shows that the model based on the first and second canonical functions explains big part $(90.5 \%)$ of total variance, moreover both functions were highly significant when tested with permutation test $(p<0.03$ and $p<0.001$, respectively, PAST software). Both measures of EQ: BMWPpl and MMI as well as the longitude and abiotic typology of the watercourses were the most important environmental variables included into the model, while Shannon index, mean phylogenetic diversity and distinctness (TDI) were the most important metrics describing diversity (Fig. 2). Variability of longitude and altitude were independent on other environmental variables while variability of rarefied species richness (IR) and TDI were independent on other components of diversity.

To show the differences in estimated species richness between groups of sites (Fig. 3) the curves describing best fitted logarithmic estimation were designed, each one with fit accuracy $\left(R^{2}\right)$ higher than 0.964 . Species richness estimated with SR for biocoenotic types IV and V were significantly higher at sites with moderate values of BMWPpl and MMI (Kolmogorov-Smirnov's test, PAST software: $p<1 \times 10^{-14}$ type IV, BMWPpl; $p<1 \times 10^{-5}$ type IV, MMI; $p<0.0112$ type V, BMWPpl; $p<0.025$ type V, MMI) while for type VI differences between groups with extreme and moderate values of EQ were non-significant.

In most cases median, third quartile and maxima of diversity indices show unimodal relationships with EQ: Shannon diversity (Fig. 4), taxonomic distinctness (Fig. 5), phylogenetic diversity (Fig. 6) and functional diversity (Fig. 7). Low values of diversity components were not dependent on the values of EQ, thus the distributions of the values of the diversity indices were, in most cases typically bell-shaped. In any case median and maximal values of any index of diversity did not increased monotonically along with the values of EQ. In most cases median values of the diversity indices and were significantly higher (65 of 84 comparisons) and their very high values (higher than percentile 0.9 ) were significantly more frequent ( 74 of 84 comparisons) at sites with moderate level of EQ (Tab. 2). The level of difference in particular components of diversity and the level of statistical significance between moderate and extreme values of EQ were visibly dependent on typological classification of the sites. Evenness was the only index which did not depend clearly on EQ in any biocoenotic type of watercourses (Fig. 4). All other indices used to measure diversity differed significantly between moderate and extreme values of environmental quality measured by BMWPpl and MMI in biocoenotic type V and those measured by BMWPpl in type IV (Tab. 2). Only indices of phylogenetic and functional diversity differed 

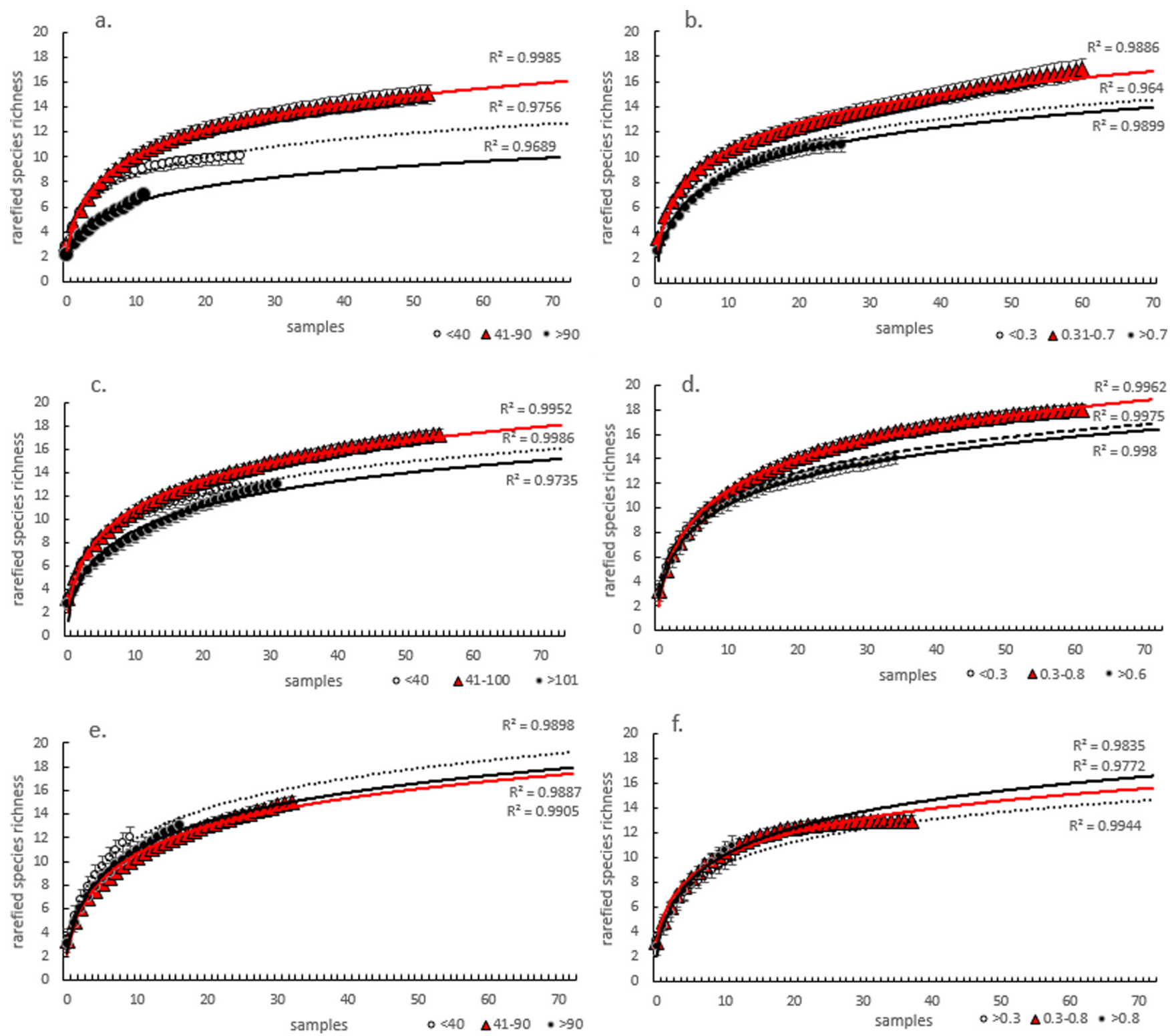

Fig. 3. Values of rarefied species richness with standard deviation (sample rarefaction with Mao Tau estimation) for groups of sites differed in terms of biocoenotic type (IV - a, b; V - c, d; VI - e, f), method of quality assessment (BMWPpl and MMI) and values of environmental quality (white circles - low, triangles - moderate, black circles - high). Values of fit accuracy of logarithmic regression curves are presented as $R^{2}$. Differences in richness between sites with moderate and extreme values presented on plots (a)-(d) are statistically significant (KolmogorovSmirnov's test).

significantly between moderate and extreme values of MMI in type IV (Tab. 2). Median values of Shannon diversity and QE differed significantly between sites with moderate and extreme values in biocoenotic type VI but only when EQ was measured by BMWPpl - in case of MMI those differences in any components of diversity was not significant (Tab. 2). Levels of statistical significance were higher for phylogenetic diversity than for other components in type IV, but higher for distinctness than for other components in type V (Tab. 2). When EQ was assessed with values of MMI at sites classified to type VI median values of any indices of diversity did not distributed unimodally (Figs. 4-7f) and their considerable variability seems to indicate other environmental factors than
EQ as a determinants of diversity. Numbers of the values higher than percentile 0.9 of almost all indices (except evenness) were significantly higher at sites with moderate than extreme values of EQ in all biocoenotic types.

\section{Discussion}

Species richness observed in studied watercourses - most common 3-5 species per sample and 17-20 species per each biocoenotic type seem to be typical for aquatic environments in Central Europe (Nesemann and Neubert, 1999; Koperski, 2006). In Polish freshwater environments 47 species of Hirudinea (Euhirudinea) were found (Bielecki et al., 2011), but 

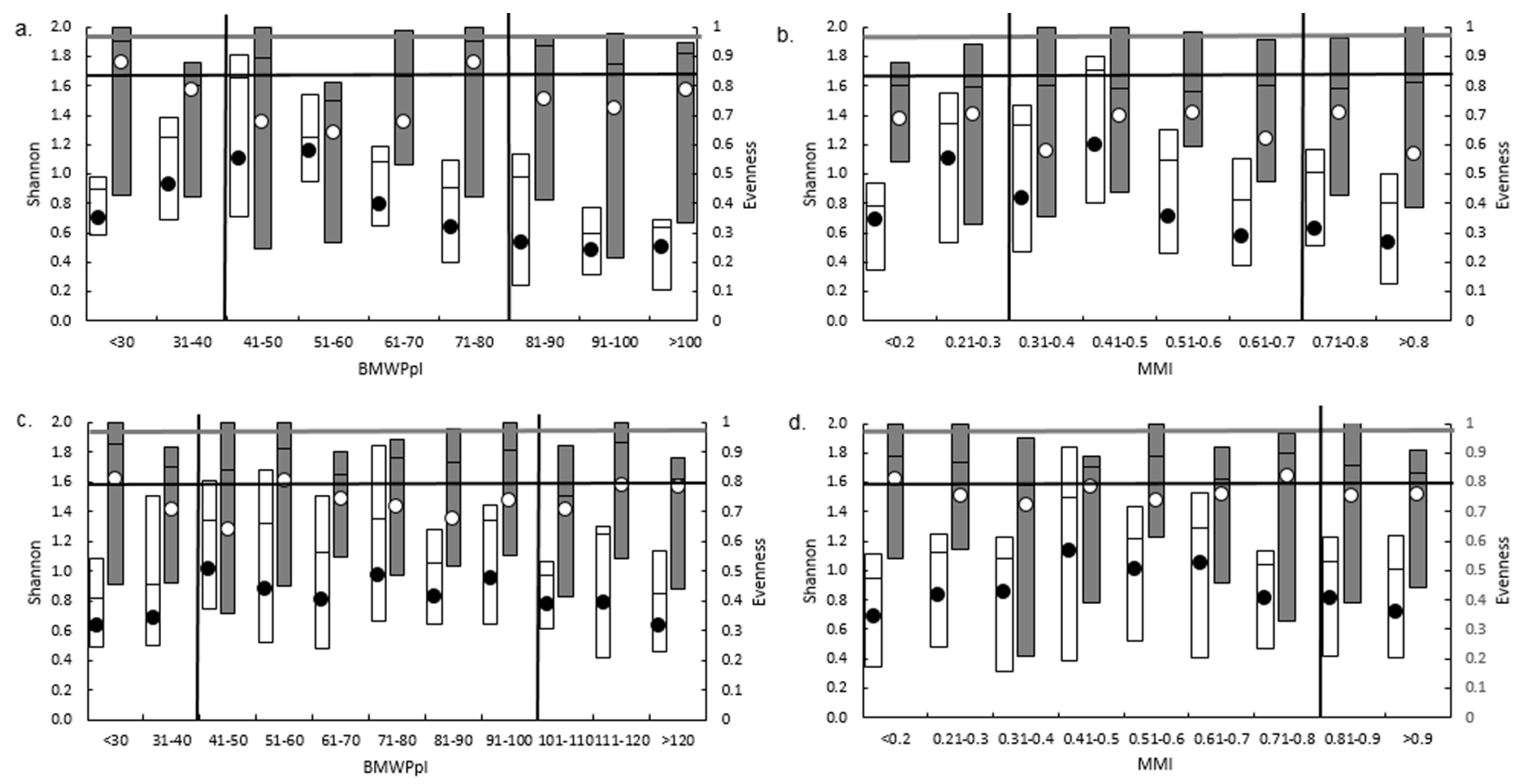

MM
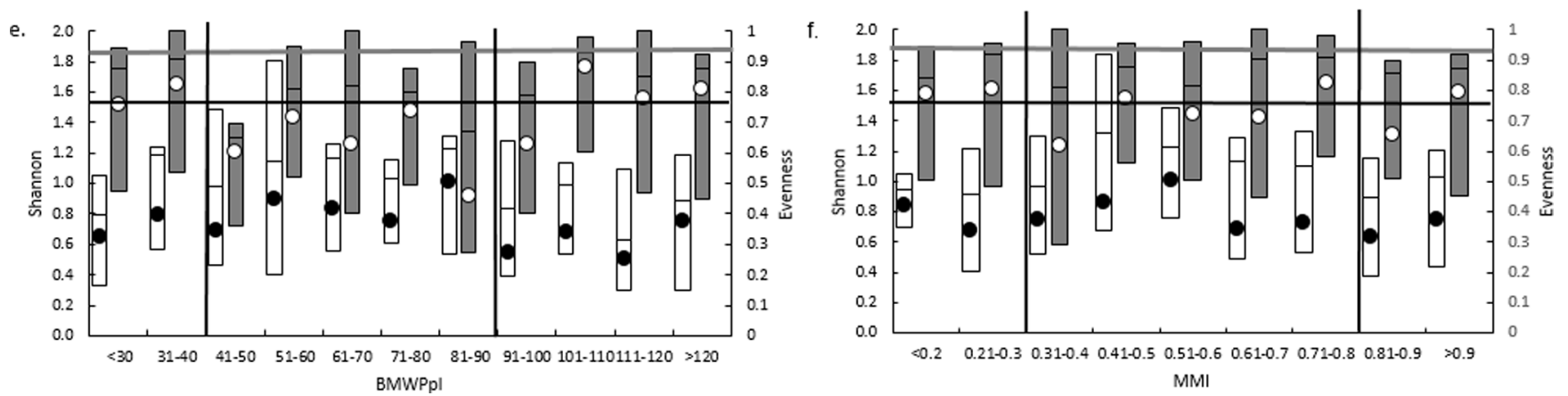

Fig. 4. The relationships between environmental quality (BMWPpl and MMI) and taxonomic diversity of leeches, expressed by the values of Shannon diversity index (white bars) and Pielou's evenness index (grey bars) for groups of sites differed in terms of biocoenotic type (IV - a, b; $\mathrm{V}-\mathrm{c}, \mathrm{d} ; \mathrm{VI}-\mathrm{e}, \mathrm{f})$. First quartile, third quartile and maximal value are shown on the bar and median values are presented as the circles. Vertical lines separate moderate and extreme values of EQ, while horizontal lines mark percentile 0.9 of both indices. Statistical significance between sites with moderate and extreme values of EQ is presented in Table 2.

the taxonomic status of certain morphological distinctive forms, mainly those belonging to family Piscicolidae are debatable (Bielecki, 1997). Nevertheless 21 species of leeches sampled in analyzing watercourses does not constitute all what one might have expected even if we ignore few species with strong preferences for standing waters. It must be emphasized that the method of sampling used in this study was not adequate for determining the abundance and diversity within the fish-leeches, family Piscicolidae - a group of obligatory fish parasites that should be analyzed on the basis of fish sampling in springtime. This may be the explanation of the relative rarity and low taxonomic richness of this group observed in sampled material. In general, the ecological preferences of particular species of piscicolid leeches remain poorly understood (Jueg et al., 2004).

Detailed data on the main geographic parameters have been taken into account as the fundamental factors for the classification of polish watercourses into biocenotic and abiotic types (Błachuta et al., 2010), consistently with the methodology recommended in other countries of the European Union (Bis and Usseglio-Polatera, 2004; Furse et al., 2006) and analogously to the hierarchical classification made for biological assessment (e.g. Frissell et al., 1986). A significant effect of abiotic typology and longitude on leech assemblages, found in this study reflects abiotic diversity within the same biocoenotic type. Weaker relationships between diversity and EQ observed in the watercourses of type VI may lead to a conclusion that this biocoenotic type is too divergent to be treated as a homogenous category. In fact, type VI contain highly disparate abiotic types of watercourses, independent on classification into ecoregions: either small streams with organic substrate, streams and rivers impacted by peatlands or rivers connecting lakes. The effect of longitude on diversity, more important than other geographic parameters probably reflects serious climatic differences between the western part of Poland (prevalence of the maritime type of climate) and an eastern one (prevalence of the continental type of climate). 

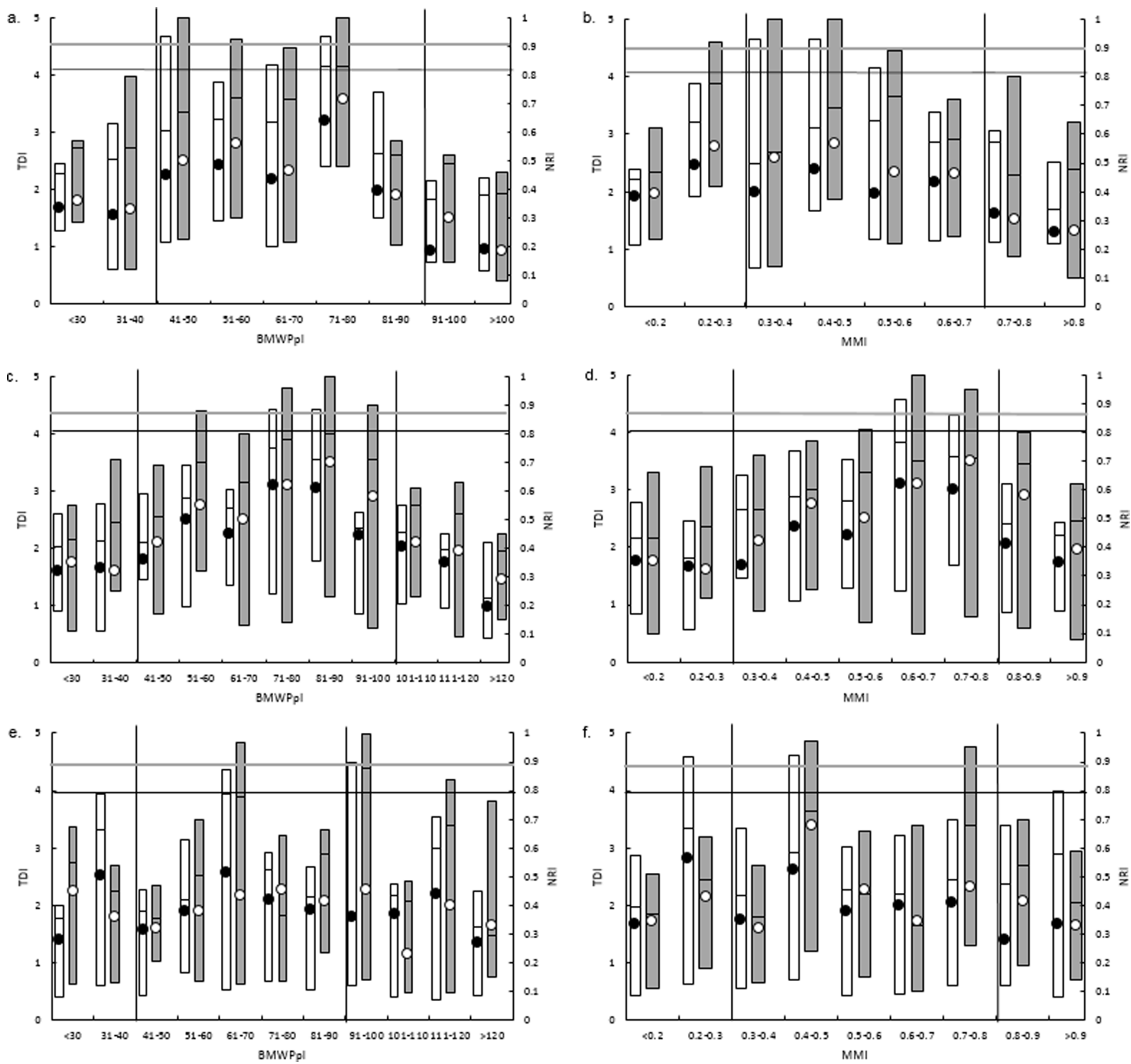

Fig. 5. The relationships between environmental quality (BMWPpl and MMI) and taxonomic distinctness of leeches, expressed by the values of taxonomic diversity index (TDI - white bars) and net relatedness index (NRI - grey bars) for groups of sites differed in terms of biocoenotic type (IV - a, b; V - c, d; VI - e, f). First quartile, third quartile and maximal value are shown on the bar and median values are presented as the circles. Vertical lines separate moderate and extreme values of EQ, while horizontal lines mark percentile 0.9 of both indices. Statistical significance between sites with moderate and extreme values of EQ is presented in Table 2.

Habitat stability and predictability as the combined effects of natural disturbance in freshwater environments were shown by Death and Winterbourn $(1994,1995)$ as important factors shaping the diversity of benthos in streams (Townsend et al., 1997). The negative relationship of invertebrate diversity with the level of degradation was observed in numerous studies, but it concerns mainly higher than species taxonomic levels of identification (Cortelezzi et al., 2013; Gutiérrez-Cánovas et al., 2013; Johnson and Angeler, 2014), e.g. family richness, calculated for benthic invertebrates strongly correlates positively with environmental quality in different watercourses (e.g. Barbour et al., 1996; Koperski and Meronka, 2017) being one of the most important metric used to assess their ecological status (e.g. Armitage et al., 1983; Bis and Mikulec, 2013). The relationships observed in present study involving identification to the species level were completely different but it would not surprise. Level of family in case of Hirudinea seems to be too coarse to bring information suitable in terms of biological assessment. Substantial differences in ecological preferences of leech species representing the same families and even the 

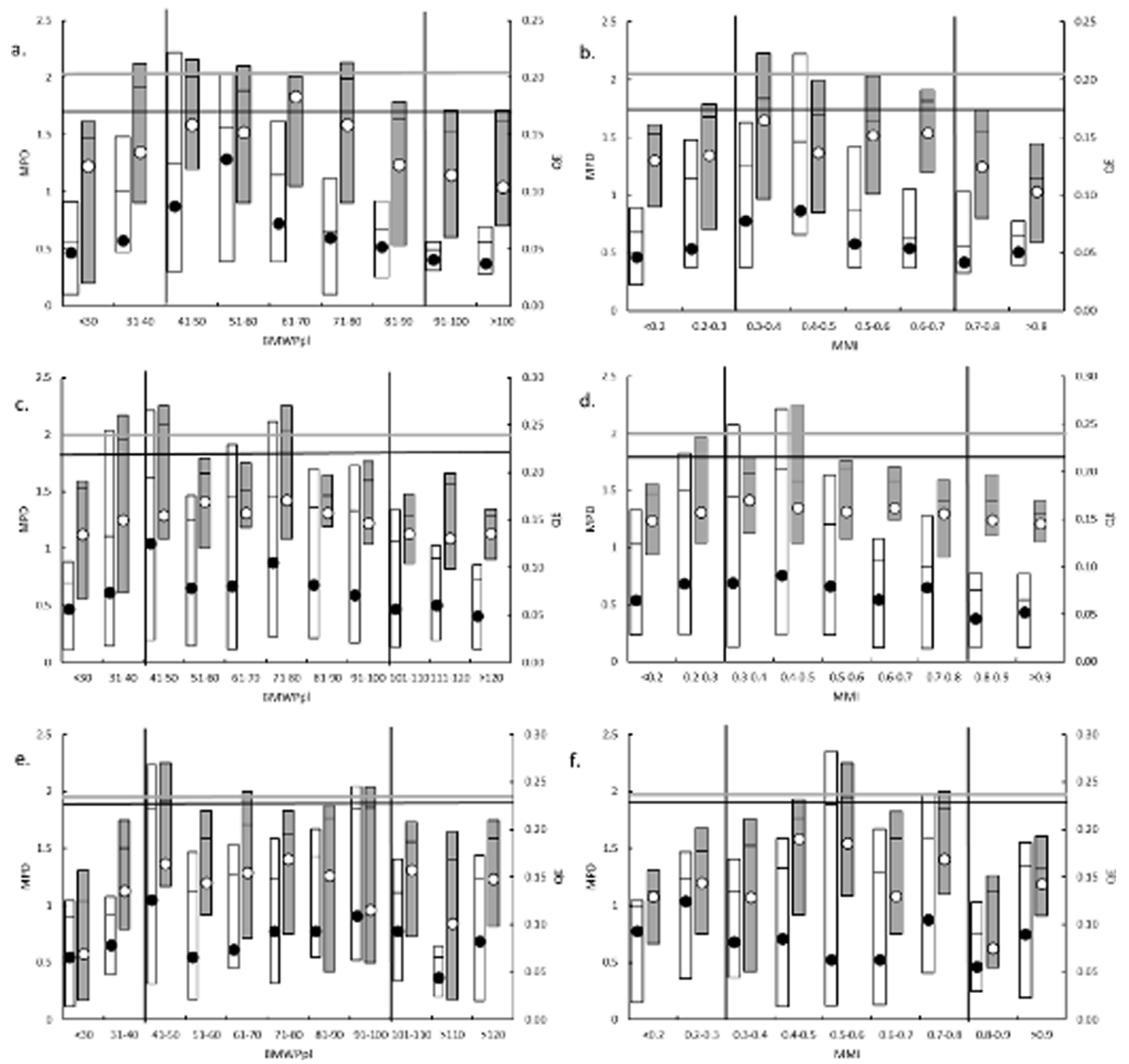

Fig. 6. The relationships between environmental quality (BMWPpl and MMI) and phylogenetic diversity of leeches, expressed by the values of mean phylogenetic distance (MPD - white bars) and quadratic entropy (QE - grey bars) for groups of sites differed in terms of biocoenotic type (IV - a, b; V - c, d; VI - e, f). First quartile, third quartile and maximal value are shown on the bar and median values are presented as the circles. Vertical lines separate moderate and extreme values of EQ, while horizontal lines mark percentile 0.9 of both indices. Statistical significance between sites with moderate and extreme values of EQ is presented in Table 2.

genera are well known and well described (e.g. Koperski, 2006; Kubová et al., 2013). E. nigricollis, T. bykowskii and Dina lineata all belonging to the same family Erpobdellidae but inhabiting completely different habitats as well as the case of two species of Glossiphonia: reophilic G. nebulosa and pond-preferred G. paludosa are also illustrative examples. The observations, that informative value of sampling for the purposes of bioassessment decreasing along with the decrease in the level of identification have been commonly presented (e.g. Verdonschot, 2006). Contrary to that, suggestions that using of higher taxa in accordance with the procedure of "taxonomic surrogacy" provide information valuable enough are even more numerous (Bournaud et al., 1996; Marshall et al., 2006). An extensive discussion of the pros and cons of both concepts presents Jones (2008) and Koperski (2011).

The mode of distribution along with the EQ gradient in the present study was unambiguously bell-shaped for almost all metrics of diversity. It should be interpreted as typically unimodal relationships deformed by the results of numerous samples collected at sites differed in terms of environmental 

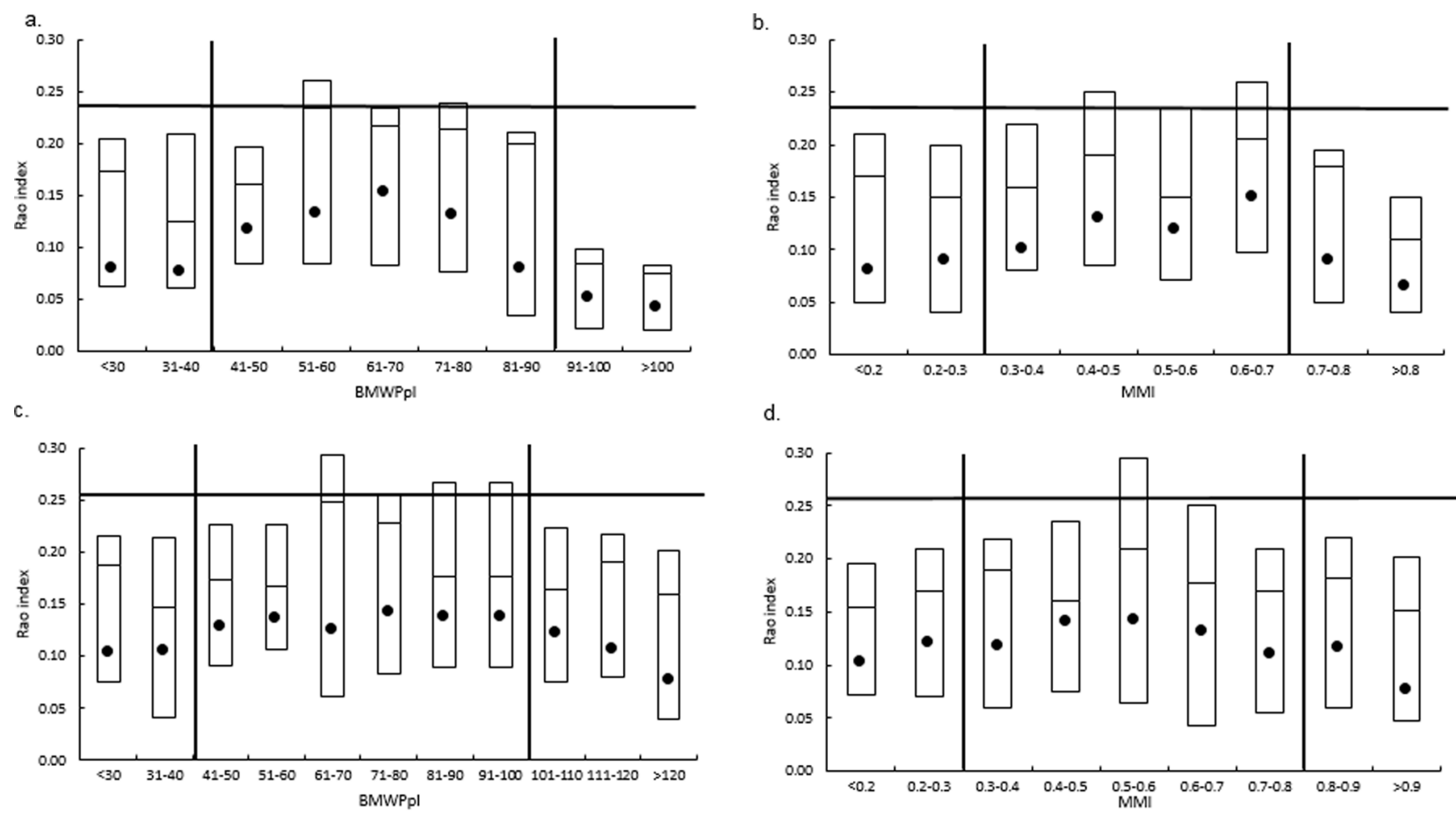

d.
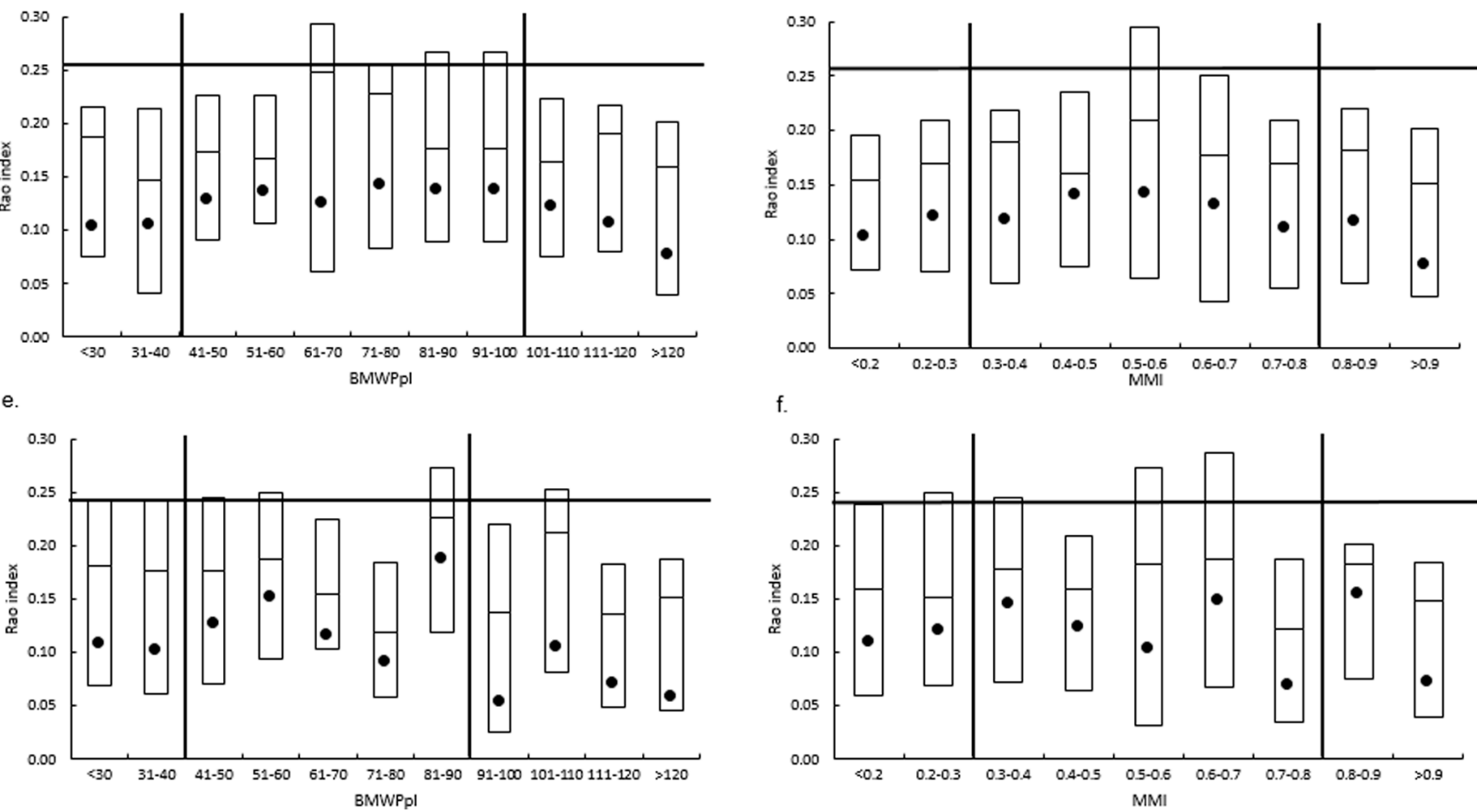

Fig. 7. The relationships between environmental quality (BMWPpl and MMI) and functional diversity of leeches, expressed by the values of Rao's index for groups of sites differed in terms of biocoenotic type (IV - a, b; V - c, d; VI - e, f). First quartile, third quartile and maximal value are shown on the bar and median values are presented as the circles. Vertical lines separate moderate and extreme values of EQ, while horizontal lines mark percentile 0.9 of both indices. Statistical significance between sites with moderate and extreme values of EQ is presented in Table 2.

quality, but with a very small number of individuals and low species richness. It should be added that this kind of bias is difficult to eliminate being a result of the sample-processing method. Sampled animals were selected randomly for further analysis using fixed-count method, in accordance with the recommended procedure (procedure RIVECO - Bis and Mikulec, 2013), required at least 350 animals randomly chosen using subsampling. Thus, as a result, leeches were found in small number in those samples which were relatively high abundances of other taxonomic groups like midge larvae or mayfly larvae.

This mode of distribution seems to confirm accuracy of concepts by Collins and Barber (1986) or Tonkin (2013). Models underlying these theories can explain the mechanisms of settlement by the species with different ecological requirements and preferences of the fragments of watercourses with different intensities of disturbance and productivity and their extinction therein. In any case monotonically negative distribution has not been shown in the present study, which means that values of diversity observed at sites with moderate quality were higher that at sites with very high quality. This monotonic relation seems to be expected in certain procedures of biological assessment based on macrobenthos identified mainly to the level of genera (e.g. Hering et al., 2006a). Bini et al. (2014) found a unimodal distribution mode for the three indices of diversity against nutrient enrichment when stream invertebrates were identified to the genus level. It is not clear which mode of relation between other components of diversity and $\mathrm{EQ}$, unimodal or monotonic is typical for samples identified to the genus level - it is obviously requires further research. 
Table 2. Results of statistical analysis of the differences in leech diversity, expressed by seven indices between groups of sites differed in terms of environmental quality, expressed by the values of BMWPpl and MMI. Analysis is presented as the results of Mann-Whitney test (differences in median values between groups, values of function $U$ and $p$ level are shown) and contingency tables (differences in number of values higher than percentile 0.9 between groups, $\mathrm{Chi}^{2}$ estimation and $p$ level are shown). Results are presented independently for each biocoenotic type.

\begin{tabular}{|c|c|c|c|c|c|c|c|c|c|c|c|c|}
\hline \multirow{2}{*}{$\begin{array}{l}\text { Comparison } \\
\text { Result diversity index }\end{array}$} & \multicolumn{4}{|c|}{$\begin{array}{c}\text { Type IV } \\
\text { BMWPpl 41-90, } N=62 v s \\
\text { BMWPpl }<40,>90, N=32\end{array}$} & \multicolumn{4}{|c|}{$\begin{array}{c}\text { Type V } \\
\text { BMWPpl } 41-100, N=61 v s \\
\text { BMWPpl }<40,>100, N=53\end{array}$} & \multicolumn{4}{|c|}{$\begin{array}{c}\text { Type VI } \\
\text { BMWPpl 41-90, } N=30 v s \\
\text { BMWPpl }<41,>90, N=30\end{array}$} \\
\hline & $\bar{U}$ & $p<$ & $\mathrm{Chi}^{2}$ & $p<$ & $\bar{U}$ & $p<$ & $\mathrm{Chi}^{2}$ & $p<$ & $\bar{U}$ & $p<$ & $\mathrm{Chi}^{2}$ & $p<$ \\
\hline Shannon & 995 & 0.049 & 5.71 & 0.017 & 1153 & 0.029 & 8.120 & 0.004 & 292 & 0.0462 & 4.140 & 0.042 \\
\hline Evenness & 808 & ns & 1.39 & $\mathrm{~ns}$ & 1314 & ns & 0.307 & ns & 360 & $\mathrm{~ns}$ & 0.387 & ns \\
\hline TDI & 710 & 0.012 & 5.71 & 0.017 & 1138 & 0.022 & 4.248 & 0.039 & 287 & ns & 5.554 & 0.025 \\
\hline NRI & 722 & 0.016 & 5.71 & 0.017 & 1112 & 0.017 & 4.930 & 0.026 & 289 & $\mathrm{~ns}$ & 4.140 & 0.042 \\
\hline MPD & 477 & $10^{-5}$ & 8.29 & 0.004 & 1157 & 0.033 & 4.960 & 0.028 & 301 & $\mathrm{~ns}$ & 4.140 & 0.042 \\
\hline Qent & 638 & $7 \times 10^{-5}$ & 8.29 & 0.004 & 1181 & 0.041 & 4.248 & 0.039 & 299 & 0.0499 & 4.140 & 0.042 \\
\hline RAO & 784 & 0.021 & 4.84 & 0.019 & 1175 & 0.042 & 4.248 & 0.039 & 306 & $\mathrm{~ns}$ & 0.387 & ns \\
\hline
\end{tabular}

\begin{tabular}{|c|c|c|c|c|c|c|c|c|c|c|c|c|}
\hline \multirow{2}{*}{$\begin{array}{l}\text { Comparison } \\
\text { Result diversity index }\end{array}$} & \multicolumn{4}{|c|}{$\begin{array}{c}\text { Type IV } \\
\text { MMI } 0.3-0.7, N=66 v s \\
\text { MMI }<0.3,>0.7, N=28\end{array}$} & \multicolumn{4}{|c|}{$\begin{array}{c}\text { Type V } \\
\text { MMI } 0.3-0.8, N=82 v s \\
\text { MMI }<0.3,>0.8, N=32\end{array}$} & \multicolumn{4}{|c|}{$\begin{array}{c}\text { Type VI } \\
\text { MMI } 0.3-0.8, N=42 v s \\
\text { MMI }<0.3,>0.8, N=18\end{array}$} \\
\hline & $U$ & $p<$ & $\mathrm{Chi}^{2}$ & $p<$ & $U$ & $p<$ & $\mathrm{Chi}^{2}$ & $p<$ & $U$ & $p<$ & $\mathrm{Chi}^{2}$ & $p<$ \\
\hline Shannon & 809 & ns & 3.22 & 0.042 & 1221 & 0.033 & 10.11 & 0.001 & 390 & $\mathrm{~ns}$ & 4.071 & 0.032 \\
\hline Evenness & 829 & ns & 1.01 & $\mathrm{~ns}$ & 1499 & ns & 1.499 & ns & 407 & ns & 0.532 & $\mathrm{~ns}$ \\
\hline TDI & 856 & ns & 5.71 & 0.017 & 1182 & 0.041 & 4.977 & 0.026 & 291 & ns & 1.554 & ns \\
\hline NRI & 888 & $\mathrm{~ns}$ & 1.13 & ns & 1186 & 0.042 & 4.248 & 0.039 & 310 & ns & 4.140 & 0.042 \\
\hline MPD & 500 & $10^{-5}$ & 5.78 & 0.016 & 1342 & 0.017 & 3.891 & 0.047 & 409 & $\mathrm{~ns}$ & 4.140 & 0.042 \\
\hline Qent & 699 & 0.021 & 3.53 & 0.038 & 1419 & 0.032 & 4.977 & 0.026 & 251 & ns & 4.140 & 0.042 \\
\hline RAO & 780 & 0.039 & 3.53 & 0.038 & 1189 & 0.048 & 3.896 & 0.048 & 294 & ns & 1.304 & $\mathrm{~ns}$ \\
\hline
\end{tabular}

Degrading factors present in studied streams were, without any doubts, very different as well as the mechanisms leading to decrease in their environmental quality. Unimodal distributions of diversity indices were repeatedly observed along with differences of divergent types of environmental degradation: catchment urbanization (Walsh et al., 2007) and nutrient loading (productivity - Rosenzweig, 1995; Svensson et al., 2007). These effects can be considered by analogy to IDH and disturbance heterogeneity (Porter et al., 2001) models. Nevertheless, Mackey and Currie (2001) concluded that unimodal relationships have the greatest odds of being observed when sampled area are small, when disturbances were classified as natural rather than anthropogenic in origin, and when few disturbance levels were examined.

Intensive discussion on the relative importance and suitability of particular components of macrobenthos diversity in assessment of different environmental stressors is probably still far from complete. The basic measure of biological diversity - rarefied species richness have been described as unimodally related with different types of environmental disturbance (Fore et al., 1996; Townsend et al., 1997; Gallardo et al., 2011); in the present study their values were also higher at moderate values of EQ. The same unimodal mode of relationship was observed also in each of the applied measures of diversity except of evenness. This index turned out to be weaker predictor of environmental quality and it had been previously stated by Townsend et al. (1997), Mackey and Currie (2001), and Johnson and Angeler (2014).
Indices based on the analysis of the biological traits of benthic animals (Functional Diversity) and those based on mutual phylogenetic relationships between species (Warwick and Clarke, 1995; Faith and Baker, 2006) are considered the most promising in prediction of environmental alterations. Charvet et al. (2000), Usseglio-Polatera et al. (2000), and Gayraud et al. (2003) indicate the enhanced usefulness of functional diversity in the biological assessment of different European watercourses when compared with other measures of diversity of benthic animals. Roque et al. (2014) found noticeable differences between traditional diversity measures and distinctness in prediction abilities to different environmental variables. This lack of congruence may be related to the fact that distinctness expresses long-term evolutionary adaptation to ecosystem conditions, while the other traditional biodiversity metrics respond to short-term environmental changes. Taxonomic distinctness, as suggested by Gallardo et al. (2011) provide especially valuable information characterizing ecosystem quality, while Shannon diversity and taxonomic richness generate important information on ecosystem conditions. Faith et al. (2009) conclude that phylogenetic diversity indices appear to be much better predictors of EQ than traditional taxonomic indices, however the use of more advanced and precise methods to assess the phylogenetic relationships among benthic animals, e.g. taking into account the relative abundance of taxa would further increase the benefits of their application (Allen et al., 2009). Mouchet et al. (2010) conclude that functional diversity 
indices have the potential to reveal the processes that structure biological communities but when combined with phylogenetic and taxonomic diversity it will help improve our understanding of how biodiversity interacts with ecosystem processes and environmental constraints.

In some cases, the analysis of the usefulness of diversity indices to assess the degradation seems questionable because of the extremely discontinuous distribution of environmental quality even if Authors confirmed their high usefulness in the assessment of anthropogenic degradation of watercourses (Göthe et al., 2015; Saito et al., 2015). When relationships between diversity and environmental quality is unimodal or Ushaped and EQ can be classified only to 2 classes accurate statistical comparison seems to be doubtful.

My results show that almost all components of biological diversity present mainly unimodal mode in response to differences in EQ. It includes traditional taxonomic indices, distinctness, functional and phylogenetic diversity and both those reflecting the relative abundance of leech species and those based on presence/absence data. Those responses were better visible in the watercourses of IV and V biocoenotic types. This conclusion seems to be interesting and can have a practical application in bioassessment but it certainly needs further research. The results suggest that all components of leeches diversity have no or at most low suitability in biological assessment of environmental quality in lowland watercourses. The use of their taxonomic compositions for these purposes also appears to be unsuitable due to strong numerical dominance of eurytopic and tolerant species in leech assemblages.

Acknowledgments. The author is grateful to General Inspectorate for Environmental Protection for the possibility to use the data and to the National Foundation of Environmental Protection and especially to Dr. Rajmund Wis niewski for great help in obtaining valuable data. Dr. Anna Sikora is acknowledged for important improvement of the text and for assistance. The study was supported by Grant 2011/01/ B/NZ9/02590 of National Science Center, Republic of Poland.

\section{References}

Allen B, Kon M, Bar-Yam Y. 2009. A new phylogenetic diversity measure generalizing the Shannon index and its application to phyllostomid bats. Am Nat 174: 236-243.

Apakupakul K, Siddall ME, Burreson EM. 1999. Higher level relationships of leeches (Annelida: Clitellata: Euhirudinea) based on morphology and gene sequences. Mol Phylogenet Evol 12: 350-359.

Armitage PD, Moss D, Wright JT, Furse MT. 1983. The performance of the new biological water quality score system based on macroinvertebrates over a wide range of unpolluted running water sites. Water Res 17: 333-347.

Bailey RC, Norris RH, Reynoldson TB. 2004. Bioassessment of freshwater ecosystems. US: Springer.

Barbour MT, Gerritsen J, Griffith GE, et al. 1996. A framework for biological criteria for Florida streams using benthic macroinvertebrates. $J N$ Am Benthol Soc 15: 185-211.

Bielecki A. 1997. Fish leeches of Poland in relation to the Palaearctic piscicolines [Hirudinea: Piscicolidae: Piscicolinae]. Genus 8.
Bielecki A, Cichocka JM, Jeleń I, S wiątek P, Adamiak-Brud Z. 2011. A checklist of leech species from Poland. Wiad Parazytol 57: $11-20$.

Bini LM, Landeiro VL, Padial AA, Siqueira T, Heino J. 2014. Nutrient enrichment is related to two facets of beta diversity for stream invertebrates across the United States. Ecology 95: $1569-1578$.

Bis B, Usseglio-Polatera P. 2004. Species traits analysis. STAR deliverable N2 to the European Commission, 148 p.

Bis B, Mikulec A. 2013. Przewodnik do oceny stanu ekologicznego rzek na podstawie makrobezkręgowców bentosowych. Warszawa: Biblioteka Monitoringu S rodowiska. Inspekcja Ochrony S rodowiska (in Polish).

Błachuta J, Picińska-Fałtynowicz J, Czoch K, Kulesza K. 2010. Abiotyczne typy wód płynących w Polsce. Gospodarka Wodna 5: 181-191 (in Polish).

Botta-Dukát Z. 2005. Rao's quadratic entropy as a measure of functional diversity based on multiple traits. J Veg Sci 16: 533-540.

Bournaud M, Cellot B, Richoux P, Berrahou A. 1996. Macroinvertebrate community structure and environmental characteristics along a large river: congruity of patterns for identification to species or family. J N Am Benthol Soc 15: 232-253.

Carew ME, Miller AD, Hoffmann AA. 2011. Phylogenetic signals and ecotoxicological responses: potential implications for aquatic biomonitoring. Ecotoxicology 20: 595-606.

Charvet S, Statzner B, Usseglio-Polatera P, Dumont B. 2000. Traits of benthic macroinvertebrates in semi-natural French streams: an initial application to biomonitoring in Europe. Freshw Biol 43: 1365-2427.

Clarke KR, Warwick RM. 1998. A taxonomic distinctness index and its statistical properties. $J$ Appl Ecol 35: 523-531.

Collins SL, Barber SC. 1986. Effects of disturbance on diversity in mixed-grass prairie. Vegetatio 64: 87-94.

Cortelezzi A, Sierra MV, Gómez N, Marinelli C, Capítulo AR. 2013. Macrophytes, epipelic biofilm, and invertebrates as biotic indicators of physical habitat degradation of lowland streams (Argentina). Environ Monit Assess 185: 5801-5815.

Darling ES, Côté IM. 2008. Quantifying the evidence for ecological synergies. Ecol Lett 11: 1278-1286.

Death RG, Winterbourn MJ. 1994. Environmental stability and community persistence: a multivariate perspective. JN Am Benthol Soc 13: 125-139.

Death RG, Winterbourn MJ. 1995. Diversity patterns in stream benthic invertebrate communities: the influence of habitat stability. Ecology 76: 1446-1460.

Directive. 2000/60/EC of the European Parliament and of the Council of 23 October 2000 establishing a framework for Community action in the field of water policy. Water Framework Directive. http://eur-lexeuropaeu/LexUriServ/LexUriServdo?uri= CELEX:3.2000.L0060:en:HTML.

European Environment Agency. 2012. "Environmental Quality (definition)" Glossary Environmental Terminology and Discovery Service (accessed on: 2012/18/06).

Faith DP, Baker AM. 2006. Phylogenetic diversity (PD) and biodiversity conservation: some bioinformatics challenges. Evol Bioinform 2: 121-128.

Faith DP, Lozupone CA, Nipperess D, Knight R. 2009. The cladistic basis for the phylogenetic diversity (PD) measure links evolutionary features to environmental gradients and supports broad applications of microbial ecology's "phylogenetic beta diversity" framework. Int J Mol Sci 10: 4723-4741. 
Fore LS, Karr JR, Wisseman RW. 1996. Assessing invertebrate responses to human activities: evaluating alternative approaches. $J$ N Am Benthol Soc 15: 212-231.

Fox JW. 2013. The intermediate disturbance hypothesis should be abandoned. Trends Ecol Evol 28: 86-92.

Frissell CA, Liss WJ, Warren CE, Hurley MD. 1986. Hierarchical framework for stream habitat classification: viewing streams in a watershed context. Environ Manag 10: 199-214.

Furse M, Hering D, Moog O, et al. 2006. The STAR project: context objectives and approaches. Hydrobiologia 566: 3-29.

Gallardo B, Gascón S, Quintana X, Comín FA. 2011. How to choose a biodiversity indicator - redundancy and complementarity of biodiversity metrics in a freshwater ecosystem. Ecol Indic 11: $1177-1184$.

Gayraud S, Statzner B, Bady P, et al. 2003. Invertebrate traits for the biomonitoring of large European rivers: an initial assessment of alternative metrics. Freshw Biol 48: 2045-2064.

Geoportal. 2013. Head Office of Geodesy and Cartography. http:// mapygeoportalgovpl/.

Göthe E, Wiberg-Larsen P, Kristensen EA, Baattrup-Pedersen A, Sandin L, Friberg N. 2015. Impacts of habitat degradation and stream spatial location on biodiversity in a disturbed riverine landscape. Biodivers Conserv 24: 1423-1441.

Grosser C, Heidecke D, Moritz G. 2001. Untersuchungen zur Eignung heimischer Hirudineen als Bioindikatoren für Fließgewässer. Hercynia 34: 101-127.

Gutiérrez-Cánovas C, Millán A, Velasco J, Vaughan IP, Ormerod SJ. 2013. Contrasting effects of natural and anthropogenic stressors on beta diversity in river organisms. Glob Ecol Biogeogr 22: 796-805.

Heino J, Muotka T, Paavola R. 2003. Determinants of macroinvertebrate diversity in headwater streams: regional and local influences. J Anim Ecol 72: 425-434.

Heino J, Mykrä H, Hamalainen H, Aroviita J, Muotka T. 2007. Responses of taxonomic distinctness and species diversity indices to anthropogenic impacts and natural environmental gradients in stream macroinvertebrates. Freshw Biol 52: 1846-1861.

Hering D, Buffagni A, Moog O, et al. 2003. The development of a system to assess the ecological quality of streams based on macroinvertebrates - design of the sampling programme within the AQEM project. Int Rev Hydrobiol 88: 345-361.

Hering D, Feld CK, Moog O, Ofenböck T. 2006a. Cook book for the development of a Multimetric Index for biological condition of aquatic ecosystems: experiences from the European AQEM and STAR projects and related initiatives. Hydrobiologia 566: 311-324.

Hering D, Johnson RK, Kramm S, Schmutz S, Szoszkiewicz K, Verdonschot PF. 2006b. Assessment of European streams with diatoms, macrophytes, macroinvertebrates and fish: a comparative metric-based analysis of organism response to stress. Freshw Biol 51: $1757-1785$.

Huston M. 1979. A general hypothesis of species diversity. Am Nat 113: 81-101.

Jackson MC, Loewen CJ, Vinebrooke RD, Chimimba CT. 2016. Net effects of multiple stressors in freshwater ecosystems: a metaanalysis. Glob Change Biol 221: 180-189.

Johnson RK, Angeler DG. 2014. Effects of agricultural land use on stream assemblages: taxon-specific responses of alpha and beta diversity. Ecol Indic 45: 386-393.

Jones FC. 2008. Taxonomic sufficiency: the influence of taxonomic resolution on freshwater bioassessments using benthic macroinvertebrates. Environ Rev 16: 45-69.

Jueg U, Grosser C, Bielecki A. 2004. Zur Kenntnis der Fischegelfauna Hirudinea: Piscicolidae in: Deutschland. Lauterbornia 52: $39-73$.
Kaygorodova IA, Mandzyak NB. 2014. Molecular phylogeny of Siberian glossiphoniidae (Hirudinea). Mol Biol 48: 452-455.

Kaygorodova IA, Mandzyak NB, Petryaeva E, Pronin NM. 2014. Genetic diversity of freshwater leeches in Lake Gusinoe (Eastern Siberia, Russia). Sci World J 2014: 1-11.

Kazanci N, Ekingen P, Dügel M, Türkmen G. 2015. Hirudinea. Annelida. species and their ecological preferences in some running waters and lakes. Int J Environ Sci Technol 12: 1087-1096.

Kondoh M. 2001. Unifying the relationships of species richness to productivity and disturbance. Proc R Soc Ser B: Biol Sci 268: 269-271.

Koperski P. 2005. Testing the suitability of leeches (Hirudinea Clitellata) for biological assessment of lowland streams. Pol J Ecol 53: 6580.

Koperski P. 2006. Relative importance of factors determining diversity and composition of freshwater leech assemblages. Hirudinea Clitellata: a meta-analysis. Arch Hydrobiol 166: 325-341.

Koperski P. 2010. Diversity of macrobenthos in lowland streams: ecological determinants and taxonomic specificity. J Limnol 69: 88-101.

Koperski P. 2011. Diversity of freshwater macrobenthos and its use in biological assessment: a critical review of current applications. Environ Rev 19: 16-31

Koperski P, Meronka R. 2017. Environmental quality of a stream can be better predicted by phylogenetic than by taxonomic diversity. Knowl Manag Aquat Ecosyst 418: 16.

Kownacki A, Soszka H. 2004. Wytyczne do oceny stanu rzek na podstawie makrobezkręgowców oraz do pobierania prób makrobezkręgowców w jeziorach. Warszawa: Zakład Ochrony Przyrody PAN (in Polish).

Kubová N, Schenková J, Horsák M. 2013. Environmental determinants of leech assemblage patterns in lotic and lenitic habitats. Limnologica 43: 516-524.

Legendre P, Legendre LF. 2012. Numerical ecology, Vol. 24. Elsevier.

Lepš J, De Bello F, Lavorel S, Berman S. 2006. Quantifying and interpreting functional diversity of natural communities: practical considerations matter. Preslia 78: 481-501.

Lorenz A, Hering D, Feld CK, Rolauffs P. 2004. A new method for assessing the impact of hydromorphological degradation on the macroinvertebrate fauna of five German stream types. Hydrobiologia 516: 107-127.

Mackey RL, Currie DJ. 2001. The diversity-disturbance relationship: is it generally strong and peaked? Ecology 82: 3479-3492.

Magurran AE. 2013. Measuring biological diversity. Oxford: WileyBlackwell.

Marshall JC, Steward AL, Harch BD. 2006. Taxonomic resolution and quantification of freshwater macroinvertebrate samples from an Australian dryland river: the benefits and costs of using species abundance data. Hydrobiologia 572: 171-194.

Mason NW, Mouillot D, Lee WG, Wilson JB. 2005. Functional richness functional evenness and functional divergence: the primary components of functional diversity. Oikos 111: 112-118.

Mouchet MA, Villéger S, Mason NW, Mouillot D. 2010. Functional diversity measures: an overview of their redundancy and their ability to discriminate community assembly rules. Funct Ecol 24: $867-876$

Nesemann H, Neubert E. 1999. Annelida, Clitellata: Branchiobdellida, Acanthobdellea, Hirudinea. Süßwasserfauna von Mitteleuropea 6/2. Heidelberg, Wien: Spektrum Akademischer Verlag.

Oceguera-Figueroa A, Phillips AJ, Pacheco-Chaves B, Reeves WK, Siddall ME. 2011. Phylogeny of macrophagous leeches Hirudinea (Clitellata) based on molecular data and evaluation of the barcoding locus. Zool Scr 40: 194-203. 
Porter EE, Forschner BR, Blair RB. 2001. Woody vegetation and canopy fragmentation along a forest-to-urban gradient. Urban Ecosyst 5: 131-151.

Reice SR. 1985. Experimental disturbance and the maintenance of species diversity in a stream community. Oecologia 67: 90-97.

Roque FO, Guimarães EA, Ribeiro MC, Escarpinati SC, Suriano MT, Siqueira T. 2014. The taxonomic distinctness of macroinvertebrate communities of Atlantic Forest streams cannot be predicted by landscape and climate variables but traditional biodiversity indices can. Braz J Biol 74: 991-999.

Rousset V, Pleijel F, Rouse GW, Erséus C, Siddall ME. 2007. A molecular phylogeny of annelids. Cladistics 23: 41-63.

Rosenzweig ML. 1995. Species diversity in space and time. Cambridge: Cambridge University Press.

Saito VS, Siqueira T, Fonseca-Gessner AA. 2015. Should phylogenetic and functional diversity metrics compose macroinvertebrate multimetric indices for stream biomonitoring? Hydrobiologia 745: 167-179.

Sánchez-Montoya MM, Vidal-Abarca MR, Suárez ML. 2010. Comparing the sensitivity of diverse macroinvertebrate metrics to a multiple stressor gradient in Mediterranean streams and its influence on the assessment of ecological status. Ecol Indicat 10: 896-904.

Schweiger O, Klotz S, Durka W, Kühn I. 2008. A comparative test of phylogenetic diversity indices. Oecologia 157: 485-495.

Siddall ME, Burreson EM. 1998. Phylogeny of leeches (Hirudinea) based on mitochondrial cytochrome $\mathrm{C}$ oxidase subunit I. Mol Phylogenet Evol 9: 156-162.

Siddall ME, Budinoff RB, Borda E. 2005. Phylogenetic evaluation of systematics and biogeography of the leech family Glossiphoniidae. Invertebr Syst 19: 105-112.

Statzner B, Bady P, Dolédec S, Schöll F. 2005. Invertebrate traits for the biomonitoring of large European rivers: an initial assessment of trait patterns in least impacted river reaches. Freshw Biol 50: 2136-2161.

Stranko SA, Hilderbrand RH, Palmer MA. 2012. Comparing the fish and benthic macroinvertebrate diversity of restored urban streams to reference streams. Restor Ecol 20: 747-755.

Svensson JR, Lindegarth M, Siccha M, et al. 2007. Maximum species richness at intermediate frequencies of disturbance: consistency among levels of productivity. Ecology 88: 830-838.

Svensson JR, Lindegarth M, Jonsson PR, Pavia H. 2012. Disturbancediversity models: what do they really predict and how are they tested? Proc R Soc Ser B: Biol Sci 279: 2163-2170.

Šiling R, Urbanič G. 2016. Do lake littoral benthic invertebrates respond differently to eutrophication hydromorphological alteration land use and fish stocking? Knowl Manag Aquat Ecosyst 417: 35.
Tonkin JD, Death RG, Collier KJ. 2013. Do productivity and disturbance interact to modulate macroinvertebrate diversity in streams? Hydrobiologia 701: 159-172.

Townsend CR, Scarsbrook MR, Doledec S. 1997. The intermediate disturbance hypothesis refugia and biodiversity in streams. Limnol Oceanogr 42: 938-949.

Usseglio-Polatera P, Bournaud M, Richoux P, Tachet H. 2000. Biological and ecological traits of benthic freshwater macroinvertebrates: relationships and definition of groups with similar traits. Freshw Biol 43: 175-205.

Utevsky S, Trontelj P. 2004. Phylogenetic relationships of fish leeches Hirudinea Piscicolidae based on mitochondrial DNA sequences and morphological data. Zool Scr 33: 375-385.

Vamosi JC, Vamosi SM. 2007. Body size rarity and phylogenetic community structure: insights from diving beetle assemblages of Alberta. Divers Distrib 13: 1-10.

Vellend M, Cornwell WK, Magnuson-Ford K, Mooers AØ. 2011. Measuring phylogenetic biodiversity. In: Biological diversity: frontiers in measurement and assessment. Oxford: Oxford University Press.

Verdonschot PFM. 2006. Beyond masses and blooms: The indicative value of oligochaetes. Hydrobiologia 564: 127-142.

Walsh CJ, Waller KA, Gehling J, Nally RM. 2007. Riverine invertebrate assemblages are degraded more by catchment urbanisation than by riparian deforestation. Freshw Biol 52: 574-587.

Warwick RM, Clarke KR. 1995. New biodiversity measures reveal a decrease in taxonomic distinctness with increasing stress. Mar Ecol Prog Ser 129: 301-305.

Webb CO. 2000. Exploring the phylogenetic structure of ecological communities: an example for rain forest trees. Am Nat 156: 145-155.

Wilkinson DM. 1999. The disturbing history of intermediate disturbance. Oikos 84: 145-147.

Wright IA, Chessman BC, Fairweather PG, Benson LJ. 1995. Measuring the impact of sewage effluent on the macroinvertebrate community of an upland stream: the effect of different levels of taxonomic resolution and quantification. Aust Ecol 20: 142-149.

Wright IA, Ryan MM. 2016. Impact of mining and industrial pollution on stream macroinvertebrates: importance of taxonomic resolution water geochemistry and EPT indices for impact detection. Hydrobiologia 772: 103-115.

Wright JF, Armitage PD, Furse MT, Moss D. 1989. Prediction of invertebrate communities using stream measurements. Regul River 4: $147-155$.

Cite this article as: Koperski P. 2017. Taxonomic, phylogenetic and functional diversity of leeches (Hirudinea) and their suitability in biological assessment of environmental quality. Knowl. Manag. Aquat. Ecosyst., 418, 49. 